\title{
Compulsory Insurance for Professional Liability
}

\author{
by Michael Faure* and Roger Van den Bergh**
}

\section{Introduction}

This paper addresses the question whether liability insurance for professional services should be made compulsory. In this respect the costs and benefits of such insurance schemes will be analysed. The authors of this paper are Belgian lawyers. Their interest in the subject is especially arisen from the typical features of liability insurance for some professional services in Belgium.

At this moment Belgian law embraces compulsory insurance for more than 40 activities. ${ }^{1}$ Among these, compulsory insurance is required for professional liability of architects and attorneys. In recent years compulsory insurance is also debated as a remedy to liability problems in the medical profession (Fagnart, Vandenberghe, 132).

The first section of the paper will give background information on the organization of the professions involved and on the extent of their professional liability. This section will also contain a description of the insurance markets involved. This information is required to make an economic analysis of compulsory insurance. It will allow us to discuss the problem not only from a theoretical point of view, but also by examing the practice of compulsory insurance for the mentioned professional activities in Belgium.

The second section of the paper is devoted to the rationales for compulsory liability insurance. Both lawyers and economists have advanced arguments in favour of compulsory liability insurance. These arguments will be summarized. This section will contain several criteria which are relevant to an efficiency analysis of compulsory insurance for professional services.

The third section of the paper analyses the insurance practice from an efficiency viewpoint on the basis of the criteria advanced in the preceding section. This analysis will Leiden.

* LL. M. University of Chicago, Attorney at the Antwerp Bar, Lecturer at the University of

** Doctor in Law, Professor at the University of Antwerp (RUCA, UIA) and at the Antwerp Business School.

The authors wish to thank those who provided information for this research and the participants of the Conference on Professional Liability Insurance, organized by the Geneva Association in Geneva on March 28-29, 1988 and of the Workshop on Law and Economics at the University of Limburg in Maastricht on May 2, 1988 for their comments.

${ }^{1}$ See the annual report of the Agency for the control of insurance companies, 1986. 
focus on the level of premiums, on moral hazard and adverse selection problems. It will also contain an analysis of the distributive effects. This will allow us to draw conclusions on the desirability of compulsory insurance for professional services in Belgium.

The fourth section will try to generalize the conclusions with respect to the Belgian situation. The legal situation in Belgium is indeed not unique. Similar arrangements exist in other European countries as well. Hence the results of the paper might carry over implications to other legal systems.

\section{Section I:}

\section{The context of compulsory insurance for professional services in Belgium}

\subsection{The organization of the professional services involved}

The profession of architect is regulated since the Act of 20 February 1939. This Act protects the title of architect. Only those who obtained a degree of architect are allowed to bear this title. The Act organizes a monopoly for architects with respect to building projects. If a building licence is required, only an architect is allowed to draw plans and to supervise the construction. An individual is not allowed to build his own house, without the participation of an architect (Rigaux, 62). The profession of architect is incompatible with that of contractor. This provision aims at preventing collusion between the architect and the contractor.

With respect to the regulation of the profession of architect, attention should be drawn upon the Act of June, 26, 1963. This Act instituted the "Ordre des Architectes". This public body, composed of architects, establishes ethical rules and imposes sanctions if these rules are violated. The "Ordre des Architectes" supervises the entry into the profession. Architects have to be admitted to an articling period and will only be officially registered after fulfilling this period.

The situation of attorneys is similar. To perform the services of an attorney one has to be licentiate in law, swear an oath to the King and be registered at the Bar. ${ }^{2}$ Only attorneys are allowed to plead a case before the courts. ${ }^{3}$ There is an Ordre des Avocats (or Bar) at each district court in Belgium. One has to be member of a Bar to perform services as an attorney. There is an articling period of three years. Each Bar formulates its own ethical rules, which can be enforced by sanctions. The Bar Council has the power to disbar an attorney if his conduct is contrary to the dignity of the attorney's profession.

Also the title and profession of the physician are protected. A person who misappropriates the title of physician can be criminally punished. The performance of medical acts is the privilege of physicians. A person who performs medical services without being a doctor can also be criminally punished.

${ }^{2}$ Article 428 of the Belgian Code of Civil Procedure.

${ }^{3}$ According to art. 440 of the Belgian Code of Civil Procedure only attorneys are allowed to plead before the courts. The title of attorney is also protected by art. 227 ter of the Belgian Criminal Code. If one uses the title of attorney, without being one, a fine can be imposed. 
Doctors are organized in one national Ordre des Médecins. To exercice the profession of a physician in Belgium one has to be member of this public body. Contrary to the situation of attorneys and architects, doctors do not have to perform an articling period after their studies. This can be explained because the stage is integrated in the study. The medical profession has a preponderant influence on the organization of the study. The Ordre des Médecins equally has the power to set ethical rules and to punish offenders. The sanctions are equal to those foreseen in the performance requirements for architects and attorneys.

\subsection{Brief overview of the scope of pressional liability}

With respect to the architect's professional liability one has to distinguish between the contractual liability and the third party liability. The contractual liability of the architect is applicable vis-à-vis the owner of the building. First of all the architect has a duty to inform the owner of the building. For instance, if the contractor would be willing to use inadequate material, the architect has a duty to warn the owner of the buliding. ${ }^{4}$ In addition the architect has to make the plans for the construction with diligence. He also has to supervise the construction of the building. The extent of this duty is debated. Some argue that the architect has no duty to be permanently present on the construction site and that his presence is only required at the construction of those parts of the building which are crucial to its solidity or its destination as well as in any circumstance in which difficult, dangerous or necessary work has to be performed (Rigaux, 316-317; Hannequart, 56-57).

With respect to the liability of the architect art. 1792 of the Belgian Civil Code merits special attention. This article holds the architect liable for the total or partial destruction of the building within a period of ten years. The destruction has to be caused by a serious defect in the construction of the building. This liability also applies to the contractor. In case-law contractors and architects are held jointly liable. ${ }^{5}$

Architects can also be held liable against third parties on the basis of negligence. For instance, if a pedestrian is hurt by a collapsing house, the architect is bound to compensate if his fault and a causal relationship with the harm suffered can be proven.

Also attorneys may be exposed both to contractual and to extracontractual liability. An important duty of the attorney is to inform his client. This duty to inform applies when the attorney is consulting a client or when a case is tried before the court. For instance, an attorney can be held liable if he omits to advise his client to go in appeal if this can be in his interest. ${ }^{6}$

In treating the case the attorney will be held liable if he does not perform the required procedural formalities: for instance, if a statute of limitations has run out or if an attorney

\footnotetext{
${ }^{4}$ Cour de Cassation, March, 3, 1978, Pas. Belge, 1978, I, 758: "Attendu que lorsque l'emploi d'un certain matériaux présente un inconvénient, l'architecte est tenu d'en avertir le maître de l'ouvrage; que, lorsque celui-ci décide, nonobstant les conseils de son architecte, d'utiliser le dit marériaux, l'architecte doit soit refuser sa collaboration si le dit emploi peut causer la perte totale ou partielle de l'édifice, soit, dans les autres cas, se faire décharger de sa responsabilité à l'égard du maître de l'ouvrage par ce dernier".

${ }^{5}$ Cour de Cassation, February, 2, 1979, Pas. Belge, 1979, I, 629.

6 Civil Cour of Nijvel, May, 28,1985, Revue Générale des Assurances et des Responsabilités, 1986, nr. 11091.
} 
forgot a term to plead. In addition, the judge will examine whether the attorney has handled with the necessary care and diligence in preparing the case. For instance, the attorney should do the necessary research on the case involved and make a proper balance of the odds that the client will win the case. In choosing the strategy for the case there is of course more freedom for the attorney. In the latter case the attorney will only be held liable if his decision differed significantly from what normally careful attorneys would have chosen to do (Depuydt, 99-101).

The attorney can also be held liable towards third parties if a fault and a causal relationship with the harm suffered can be proven. The fault can consist in a violation of the general duty of care and in a violation of a legal norm. Although an attorney is immune in his freedom of pleading the case, a diffamation suit can be filed against him if he unnecessarily causes harm to the honour of third parties. ${ }^{7}$

After previous hesistations in legal doctrine it is now generally accepted that the physician is contractually liable. Of course a doctor is not bound to guarantee a good health as a result of his treatment, but he is obliged to take the care a normally careful physician would spend in treating his patient. In choosing the therapy the doctor has to rely on the current state of the medical science (Kruithof, 182-183). The appreciation of the fault of the physician by the court causes difficulties. Especially difficulties of proof arise. Often the court appoints an expert, who is a colleague of the defendant. He might be insufficiently independent to examine the required care appropriately. Moreover doctors are bound by a professional secret, which hinders the appreciation of their behaviour. This might explain why in case-law most cases where a doctor is found liable concern the duty to perform a specific task. One could mention a blood examination or an amputation of the wrong leg. Other cases where liability of the physician has been established concern the duty to monitor the patient after treatment or operation. ${ }^{8}$ It should be mentioned that for every medical treatment the consent of the patient is required. A doctor who would perform an operation on a patient without his consent could even be criminally prosecuted (Vandenberghe, 128-129).

\subsection{The insurance markets}

Originally most of the larger Belgian insurance companies offered insurance policies covering the professional liability of architects. With liabilities of architects expanding, premiums raised. Nowadays the larger insurance companies only play a minor role in covering the risk involved. This can be attributed to the information required for covering professional risks. The insurer needs information about the actual liabilities to which the architect is exposed. Apparently such information can better be obtained by smaller insurance companies which specialize in this branch of insurance.

${ }^{7}$ Article 444 of the Belgian Code of Civil Procedure; article 452 of the Belgian Criminal Code.

${ }^{8}$ Court of Appeal of Liège, June, 25, 1986, Jurisprudence de Liège, 1986, 674 ; Court of Appeals of Mons, October, 14, 1985, Revue Générale des Assurances et des Responsabilités, 1986, nr. 11093 ; Criminal Court of Brussels, December, 13, 1985; Revue Générale des Assurances et des Responsabilités, 1986, nr. 11092 . 
Currently three specialized insurers are covering architects liability on the Belgian market. The major Belgian insurance company Josi has a subdivision, called A.I.A., covering the architects' liability. The second specialized insurer, called A.I.M., is a German insurance company with a Belgian subsidiary in Brussels. The largest insurer is ARCO : a mutual insurance company under the legal form of the société coopérative. This mutual has been set up in 1963 to remedy the unwillingness of the traditional insurers to cover the ten-year-liability, discussed above. Shareholders of this company are mainly architects, who appoint a board of directors. ARCO is run on a non-profit basis. Profits are shifted to the financial reserves, which allows the company to keep premiums at a constant level. Larger insurance companies are still involved in covering the professional liability of architects, since they often provide reinsurance for the larger risks.

Liability insurance policies for attorneys are not entered into on an individual basis. The contracts are drafted on a collective basis between representatives of the different Bars and the larger brokers. For instance, in the Dutch speaking part of Belgium, nine Bars are insured through a large brokerage firm in Antwerp which places the risk at several insurance companies. Interesting to mention is the decline of the number of insurance companies offering coverage for attorneys' liability. Ten years ago, when liability insurance for attorneys became generalized, approximately 20 insurers were active in this market. Several problems, especially high moral hazard and increasing accident rates, led to the canceling of many policies and the withdrawal of several insurers from that market. At this moment five insurance companies cover attorneys' liability. These companies are: Royale Belge, De Ster, A.G.F. (Assurance Générales de France), Urbaine U.A.P. and A.B.B. (the insurance company of the Belgian Farmers Union).

Each doctor has the possibility to insure his professional liability on an individual basis. Many of the traditional insurance companies on the market offer policies covering medical malpractice. There is one specialized insurance company, called "The Medical". Contrary to ARCO, The Medical is not a mutual insurance group of doctors, but a commercial insurance company.

\section{Section II :}

\section{Arguments in favour of compulsory liability insurance}

\subsection{Introduction}

In legal doctrine pleas in favour of compulsory liability insurance are often heard. A duty to insure is seen as a guarantee to the victim. If insurance is available, the victim will always receive compensation. The favouring of compulsory liability insurance can be explained by the concern for victim protection. To many lawyers the main purpose of accident law is the compensation of the innocent victim. Compulsory liability insurance could remedy the potential insolvency of the injurer.

In the largest part of economic doctrine, different benefits of liability insurance are stressed. Insurance is considered to be a benefit to risk-averse injurers whose utility can be increased by shifting the risk to an insurance company. This shift will raise social welfare and is therefore beneficial. Hence, in the eyes of the economist liability insurance is a benefit to the injurer, whereas lawyers stress the benefit for the victim.

Of course there has to be no contradiction between the lawyers view and the economists'. Although the underlying ideas are different, the fear of the lawyers for the insolvency 
of the injurer implicitly contains an economic argument. The insolvency can create an externality which is not internalized without the duty to insure.

It should also be stressed that the benefits of liability insurance advanced by economists only prevail under a set of stringent assumptions. Insurance markets have to be competitive ; moral hazard has to be cured and adverse selection should be excluded. We will now examine under which conditions the benefits of liability insurance are that high that the purchase of insurance should be made compulsory for professionals. In the following part of the paper we will give an overview of the possible arguments in favour of compulsory liability insurance and test their validity. Special attention will be paid to the question whether compulsory liability insurance can cure several inefficiencies (insolvency, informational deficiencies).

\subsection{Increasing the expected utility}

An extensive literature on the demand for insurance has shown that insurance will increase social welfare by taking away risk from risk-averse persons (Arrow, Borch, Pratt and Raviv). These benefits of insurance are undebated. However, they are not that high that they warrant the introduction of a duty to purchase liability insurance. Indeed, the demand for insurance depends upon a variety of factors. The degree of risk aversion varies among the individuals. Some very wealthy individuals might only be slightly risk-averse or even risk-neutral to casualties which are for them relatively small risk. This illustrates that a generalized duty to purchase liability insurance could have a negative impact on social welfare. Under a compulsory liability arrangement, individuals may be forced to pay insurance premiums which do not increase their utility since they exceed the expected losses.

Therefore the analysis of the demand for insurance alone can not explain why liability insurance should be made compulsory. Even if empirical proof would show that most individuals of a certain group are highly risk-averse, making liability insurance compulsory could still create a social loss, although this may be smaller. Assuming that individuals have perfect information on the risks involved and the availability of insurance, the mere fact that insurance might increase their expected utility is not an argument for making liability insurance compulsory. ${ }^{9}$

\subsection{Compulsory liability insurance as a remedy to insolvency problems}

If a potential injurer causes an accident creating losses exceeding his personal wealth, victims may remain uncompensated. This cost might be thrown on society, which creates the need for inter alia healthcare and compensation for lost earnings. Hence, the externality will, in case of insolvency, not be internalized by the potential injurer.

It should, however, be noticed that the loss to society will be greater under a strict liability rule then under a fault rule. In the literature it has been shown that the insolvency of the potential injurer leads to serious problems of underdeterrence if the harmful activity is subjected to a strict liability rule. Under a fault rule a potential injurer will take efficient

9 Even if one would reject the expected utility hypothesis as starting point for analyzing the demand for insurance, this finding does not change. Other theories of insurance, e.g. the prospect theory provide an alternative explanation why people insure (see Kahneman and Tversky). However, this theory does not advance arguments in favour of compulsory insurance. 
care as long as the costs of taking care are less than his assets. This will often be the case. Under a strict liability rule an injurer has no incentive to take optimal care if the loss will exceed his assets. Even if he takes due care, he will have to pay for the total damage. It follows therefore that the insolvency problem will not as easily lead to a problem of underdeterrence if a fault rule is applied (Landes and Posner; Shavell, 1986).

Notwithstanding the possible benefits of compulsory insurance in case of insolvency, the question arises whether the insolvency externality can not be cured at lower costs. One could think of different alternatives. First, compulsory first party insurance could be considered. In European countries such insurance schemes exist in the field of health care. Also social security may provide adequate compensation for victims. First-party insurance better enables the narrowing of risk pools. Because the insurer is aware of the special characteristics which affect the risk (e.g. age, occupation and income of the insured) the first-party insurer can segregate between low risks and high risks. This implies that the adverse selection problem can be better overcome than under liability insurance. In first party insurance a narrowing of risk pools where premiums correspond with the expected losses of the insured is easier to perform than with third party insurance (Priest). However, one should be cautious with first party insurance as well, especially when it is provided by the government. In the latter case high administrative costs and inefficiencies created through bureaucracy might cancel out the advantages of first party insurance, partially or totally.

An alternative device would be the institution of a compensation fund. The financing of such a fund is possible through different devices: taxes or levies on potential injurers. The fund would intervene to pay compensation if the injurer appears to be insolvent. At first sight such compensation fund seems to have several advantages in comparison with compulsory liability insurance. A fund could operate without impairing the deterrent effect of liability rules. Moral hazard problems, inherent in every insurance system, could thus be avoided. In addition, the costs of operating a fund could be lower. Indeed, the fund only intervenes if an injurer is insolvent. Under compulsory liability insurance the administrative costs seem to be higher, since the insurer pays compensation for every accident, whether the injurer was insolvent or not. Finally a fund could avoid the above mentioned welfare loss. Compulsory liability insurance forces all injurers to purchase liability insurance, whether this increases their expected utility or not. Although risk-neutral injurers still would have to pay a tax to finance the fund, this will involve an inferior utility loss to them. Insurance premiums will generally be higher than the contributions to let the fund operate. Moreover, if injurers would be risk-averse, they could still purchase insurance coverage taking into account their own degree of risk-aversion.

In sum, compulsory liability insurance can remedy the insolvency risk, but is not necessarily the most efficient way to solve this problem. Alternative devices which overcome the insolvency externality at lower costs should be considered. In this respect one could wonder why compensation funds are not more often found in legislation. The economics of lobbying and pressure groups might provide an explanation. The introduction of compensation funds is clearly not in the interest of the commercial insurance industry. ${ }^{10}$ In the same

${ }^{10}$ During the discussions preceding the European Directive on products liability of July, 25, 1975, the installment of a compensation fund for product damage as an alternative to producer liability was proposed. Due to strong opposition of insurers who prefered individual producer liability (!) this proposal did not succeed (see Van Empel and Ritsema, 53). 
context, it is interesting to notice that Belgian law shows a combined use of insurance schemes and compensation funds. In the areas where compensation funds exist, liability insurnce is often also made compulsory. ${ }^{11}$

\subsection{Informational problems}

Informational problems are regularly advanced as reasons for regulatory intervention in markets. In the context of liability insurance, the problem of information appears under two different features. The first is the information necessary for the injurer to judge his demand for insurance. The second is the informational asymmetry between insureds and insurers.

To maximize his own utility an injurer needs exact information on his exposure to risk and on the availability of insurance. This will allow him to make an efficient decision with respect to the purchase of insurance coverage. If this information is imperfect, the assessment of the demand for insurance will be negatively influenced. An underestimation of the risks involved might lead an injurer to decide not to take liability insurance, although this would increase his expected utility. To overcome this informational problem a legislator might decide to make the purchase of liability insurance compulsory. This could, together with the above mentioned insolvency problem, explain the generalization of compulsory liability insurance for car drivers in Europe. If informational deficiencies exist, compusory liability insurance could indeed be the adequate remedy. It might, however, be difficult to distinguish betweem informational deficiencies and irrationality of injurers. If the legislator would force fully informed injurers to purchase liability insurance, because it is considered for their good, this could be considered a paternalistic measure.

In his seminal publication "The market for lemons" Akerlof has shown how informational asymmetry can create inefficiencies. In the context of insurance the problem of informational asymmetry appears as the adverse selection problem. When an insurer can not separate the good risks from the bad ones, the premium will be set at an average level. This will induce the good risks to leave the pool. The problem is that insureds do know whether they pose a lower risk than average and therefore have an interest in leaving the risk pool (Akerlof).

It has been suggested to cure these problems through a system of compulsory insurance. Pauly has pointed out that the government might by able to gather the information on the risks involved at lower costs than the insurer. In that case the government should make the information available to the insurers or should provide insurance itself. This point of view is shared by other leading insurance economists (Rothschild and Stiglitz; Johnson). In sum, if the adverse selection problem is serious, compulsory insurance might cure the informational asymmetry. Government provided compulsory insurance is the most obvious solution under these circumstances.

\subsection{The benefits of compulsory insurance refined}

The possible increase of social welfare by making insurance compulsory might be canceled out through serious moral hazard problems and through competition restrictions on the insurance market. In the final assessment of the desirability of compulsory, third party liability insurance schemes, other possible disadvantages should be taken into

11 This is the case in Belgium e. g. by industrial accidents and by car accidents. 
consideration, such as the operational costs of the system and the enforcement problem. Section 4 will focus on the latter aspect.

It is well known that liability insurance has negative effects on the incentives to take efficient care. If this moral hazard problem can not be cured, the benefits of compulsory insurance decrease or might even disappear. There are two possible remedies to moral hazard: exposing the insured partially to risk or monitoring the insured and adapting the premium accordingly. The first possible remedy is often excluded by law. Statutes introducing a duty to insure often force the injurer to take full insurance coverage. As a consequence the care taken by the potential injurer will totally depend upon the monitoring of the insured by the insurance company. If this monitoring is ineffective, the moral hazard problem remains. If therefore, under a system of liability insurance, a serious moral hazard problem would remain, the effect of making such insurance scheme compulsory would overall be negative. If in that case the policy makers would desire to take any regulatory action with respect to liability insurance, the purchase of liability insurance should be prohibited instead of made compulsory (Shavell, 1979, 1986).

Until now it has been assumed that insurance markets are perfectly competitive. Reality is significantly different from the model of perfect competition. If a high degree of concentration on the insurance market exists, premiums will not be calculated at actuarily fair levels. They will be higher than the expected loss, not only due to loading, but mainly due to monopolistic price setting. This changes the appreciation of the benefits of liability insurance and hence the judgement on compulsory liability insurance. When premiums highly exceed the actuarily fair level, insurance will not increase the expected utility of injurers any longer. Under these circumstances, a regulatory action making insurance compulsory will create a social loss. The concentration on the insurance market does not only have a negative influence on the optimal risk spreading. It is also detrimental to the incentives of the insurer to control moral hazard. Empirical studies on the concentration on the German insurance market have shown that a high degree of concentration together with strict premium regulations increases the accident level (Adams and Finsinger). This can easily be understood. Concentration might lead to monopolistic profits, which dilute the incentives of the insurer to control moral hazard effectively.

\section{Section III :}

\section{Compulsory insurance for professional liability in the Belgian practice}

To make an assessment of the desirability of compulsory insurance on the basis of the criteria discussed in the preceding section, information is needed on the functioning of the insurance market. This paper will use the Belgian case as an illustration. Subsequently we will discuss the history of compulsory liability insurance; the currently available insurance policies, the level of premiums and the extent of moral hazard and adverse selection.

\subsection{Architects}

\section{- History}

The duty to insure is imposed on achitects through the rules of professional ethics. The purchase of liability insurance is therefore in fact compulsory. The ethical rules of 1967 provided in art. 22 that an architect should take measures to be able to pay in case he would 
be held liable. An insurance contract is the most obvious necessary precaution. The new rules of 1985 have introduced an explicit duty to insure. These rules have been approved by Royal Decree. ${ }^{12}$ Article 15 of the ethical rules provides the following:

"The architect insures his civil professional liability, including the ten year liability.

This insurance will be a part of a general compulsory insurance for all the parties involved in the construction."

The formulation of this text is rather odd. It is clear that the ten year liability is part of the architect's professional liability, since it concerns its most important component. The second sentence implies that in the view of the architect both the owner of the building and the contractor should be forced to take insurance coverage as well (Baert).

The publicly pronounced reason for the duty to insure can be found in the statement to the King: it is to protect the dignity of the architect (Boulanger). According to spokesmen of the Architect's Association the professional organization wanted to protect the architect against the expanding liability. They informed us that before 1985 , when the duty to insure was introduced, only $10 \%$ of all architects possessed liability insurance. The others were said not to have been aware of the high risks.

Today both architects and insurers feel unhappy about the compulsory insurance arrangement. Insurers fear that the duty to insure will bring bad risks into the insurance pool. Especially those architects who are not aware of the risks involved are now forced to join the insurance pool.

The arguments of the architects against the compulsory liability insurance are more complex. First they complain about the high level of premiums. Second, they fear that through the existence of liability insurance coverage, it will be impossible to turn back their expanding liability in case-law. Third, they argue that through too much uncertainty in caselaw with respect to the extent of architects liability, premiums will easily exceed the expected losses. This can be illustrated as follows. Under Belgian law it is possible to hold the architect and the contractor jointly liable. The existence of this "in solidum" liability rule implies that the architect is exposed not only to the risk of being held liable for his own faults, but also for the faults and the insolvency of the contractor (Beeck and Boulanger). Fourth, the existence of liability insurance will lead to excessive requirements from the insurer. For instance, architects are often required to take a ground test, even if this will not decrease the accident risk. This problem is due to a lack of individual monitoring and leads to excessive precautions and an increase of the building price. Finally, they fear that the availability of insurance coverage will increase the extent of liability. It will induce owners to file more law suits against architects, knowing that they are insured. This fear is affirmated by a tendency in Belgian case-law to hold a person liable who has insurance coverage. This will of course lead to an increase of insurance premiums (Baert and Beeck).

These arguments throw a new light on the odd formulation of art. 15 of the ethical rules discussed above. By referring to a general compulsory insurance system the architects wanted to induce the purchase of insurance by the other parties involved in the construction. They are lobbying to introduce a general duty to insure for owners of buildings. Their efforts have not been successful yet. On the other hand, their criticisms led to a lack of

12 Royal Decree of April, 18, 1985, Moniteur Belge, May, 8, 1985. 
enforcement of the duty to insure. The enforcement of the professional ethics is entirely entrusted to the architects' professional organization. There are no criminal sanctions in the Royal Decree. As a result of the intended non-enforcement by the professional organization, only $30-40 \%$ of architects are insured today. These are estimates of the architects. According to information given by the insurer around $60 \%$ of architects would have insurance coverage. This still leaves $40 \%$ uninsured.

- The insurance policy

ARCO insures 1,200 architects. Since this is the largest share of the market, we will mainly focus on the policy provisions of this company. For every architect the same general conditions apply. Policies are not drafted on an individual basis. The premium is calculated on the value of the building involved. It amounts to $1,20 \%$. In case the architect has a full contract. ${ }^{13}$ The underlying idea of this calculation is that the liability increases with the value of the building. This basic premium of $1,20 \%$ only covers buildings up to a value of 100 billion Belgian francs. Once this threshold is passed the premium raises to $1,35 \%$.

The payment in case a sinister occurs, is basically limited to 10 billion Belgian francs. This amount covers both bodily harm and material damage. If the architect desires a higher amount of coverage, the premium raises again. It amounts to $1,80 \% 0$ for a coverage of 15 billion francs and to $2,40 \%$ for an insurance coverage of 20 billion Belgian francs.

Since policies are not drafted on an individual basis, the premium calculation is basically the same for every architect. Only the value of the building involved is decisive. The qualifications of the architect are not considered. In the premium calculation the type of work performed by the architect is taken into account. A full contract is not always at hand. For instance, if an owner builds his house himself, he only needs an architect for the formalities (e. g. the building licence). In this case the liability of the architect is considered to be lower. He will have to pay a premium of only $0,50 \%$ on the value of the building. This is the only kind of individualization of premiums known.

It is useful to mention that the insurance policy covers both the contractual liability towards the owner, as the ten year liability and the extracontractual liability of the architect for damage caused to third parties.

- Moral hazard and adverse selection

Different devices can be found in insurance contracts covering architects liability to overcome moral hazard. It should, however, be noticed that the possibilities of monitoring seem restricted by professional ethics. Differentiation in premiums is highly disliked among architects, since this would imply to distinguish the good architects from the bad ones. Suboptimal monitoring might be the consequence. Moreover, this danger is more apparently present with respect to the insurance policy of $\mathrm{ARCO}$, which is a mutual of architects.

There is no ex ante monitoring by ARCO. All architects are considered to be good risks and the premium is equal for all. Also ex post there is no premium reduction for architects who have shown to be good risks. If an architect can show that no liability claim has been filed against him during several years, he can not benefit from a premium reduction. Neither do other types of experience-rating exist. In the opposite case, where

13 This means that if the value of the building is 2 billion Belgian francs, the premium for the architects liability for that building is 2.400 Belgian francs. 
one architect causes many accidents, he will in principle not be subjected to a premium increase. In sum, there is no individualization of premiums, neither ex ante, nor ex post, neither for the good risks, nor for the bad ones.

Since monitoring is suboptimal, the further question should be addressed whether moral hazard is cured through exposing the insured partially to risk. There is indeed a generalized deductible of $10 \%$ with a minimum of 25.000 Belgian francs. It concerns a fixed deductible, which does not vary according to the individual architect. There is however an exception. Spokesmen informed us that if too many accidents happen, which leads to the suspicion that the harm is caused intentionally or due to serious professional faults, the insurance company can increase the deductible. In serious cases of misdemeanours of an architect, his policy will simply be canceled. The policy of ARCO gives indeed a far reaching right to cancel the policy without stating any reason.

The absence of individual monitoring and the all or nothing approach towards bad risks, leads to severe duties for the insured architect. For instance, the policy forces the architect to perform a thorough examination of the soil for every building project. Architects hold that this is an unnecessary precaution. In their view the insurer increases the safety standards in a excessive way. This could lead to an increase of the costs of the whole building project. An even more illustrative example is the following practice of ARCO. Architects are forced to use specially drafted contracts to which the owner should agree and in which the liability of the architect is limited. In this respect one can finally mention that the policy gives ARCO the right to visit the plant.

With respect to the adverse selection problem, the insurer fears that the introduction of compulsory liability insurance might exactly cause this inefficiency. His reasoning runs as follows. In the absence of the duty to insure, only responsible architects, being mostly the good risks, will buy insurance coverage. A duty to insure causes only the bad risks to join the risk group. This argumentation is of course only valid in the special Belgian situation. As mentioned above, the duty to insure is not fully enforced. Otherwise, the good risks would have to stay into the pool and the adverse selection problem might be excluded.

\subsection{Attorneys}

\section{- History}

Liability insurance for lawyers was prohibited for a long period. During the last century and even until World War II, it was considered to be an unjustifiable kind of exoneration of liability. In the 1940's a few Bars started to accept liability insurance if certain strict conditions were met. For instance, the executive of the insurance contract could never lead an attorney to act contrary to any rule of legal ethics. An attorney was especially not allowed to violate his professional secret (Depuydt, 228). After the second World War liability insurance has been allowed without any restriction. Nowadays the introduction of compulsory liability insurance for lawyers by statute is discussed as the next step in this evolution.

Although there is no statutory duty to insure, Belgian attorneys are in fact forced to purchase insurance coverage for their liability through their membership of the Bar. It has been mentioned above that one has to be member of the Bar to perform the service of an attorney. The Bars have each individually negotiated with insurance companies to get collective insurance policies in favour of all attorneys who are a member of the Bar. The 
premium for the collective insurance policy is spread over all attorneys through their membership fee to the Bar. The premium constitutes in fact a part of this fee. To become a member of the Bar, the attorney has to pay the insurance premium through his membership fee, whether he wants to benefit from the collective insurance policy or not. There is no possibility to become a member of the Bar without participating in the collective liability insurance policy.

In 198222 of the 27 Bars had a compulsory insurance system based on a collective policy. Three Bars had no such arrangement and did not force their member-attorneys to purchase liability insurance. The Bar of Dendermonde had a collective policy but the participation of the attorneys was optional. Nevertheless, attorneys were forced to insure their liability according to a rule of legal ethics. They had the choice either to join the collective policy or to prove that they insured their liability on an individual basis. Finally the attorneys in the district of Nijvel did not have a collective policy, since it had been canceled by the insurance company. In the last mentioned district a duty to insure is imposed as a rule of legal ethics as well (Depuydt, 267).

In sum, in most Belgian Bars some type of compulsory liability insurance exists. Only in small districts the duty has not been imposed yet. It should be asked why most Bars decided to provide collective insurance policies on a compulsory basis. Spokesmen informed us that it was especially aimed at the protection of the dignity of attorneys. In the absence of compulsory insurance attorneys who pose bad risks and cause many accidents would often not bother to insure their liability. This could imply that clients remain uncompensated in case of insolvency of the attorney. It was argued that such occurrences would damage the dignity of the Bar in general and especially the interests of the respectable attorneys. A compulsory insurance through a collective policy would assure the public that the Bar is able to pay if accidents happen. One recognizes the free riding problem. Compulsory liability insurance avoids that unscrupulous attorneys would benefit from the good reputation of the Bar in general without contributing in the expenses. In addition, Depuydt argues that the compulsory insurance also protects the attorney. If an accident happens he could be forced to pay billions, which would ruin his total carreer (Depuydt, 230). Here one can recognize the paternalistic argument in favour of compulsory liability insurance.

- The insurance policy

The insurance policy covers the civil liability of the attorney. This risk embraces both the contractual liability towards the client and the third party liability. The first one is the most important in practice. The loss is covered, whatever its cause: negligence, mistake, forgetting a term, loss of documents. The terms of the insurance policies are very similar as far as the description of the risk is concerned. Exclusions concern all acts not committed in the course of his profession by the attorney. Also if the insured fulfils another position than attorney-at-law in its strict sense, e.g. trustee in bankruptcy, director of a corporation, the policy does not provide coverage for that risk, unless it is expressly agreed.

The insurance policy covers also the fault committed by associates or clerks of the insured attorney. Also a fault committed by an employee is covered.

In all policies covering attorneys' liability the insured amount is limited. The maximum is different for the policies in various Bars. In 1982 Depuydt discovered that the limitation 
varies from 5 billion Belgian francs ${ }^{14}$ to 15 billion. ${ }^{15}$ For reasons unknown in Charleroi the coverage amounted to 50 billion Belgian francs (Depuydt, 267). We investigated the policies of some Bars and found that the limitation of coverage has not been raised since then. It should, however, be mentioned that with respect to the third party liability of the attorney, coverage is available for much higher amounts. In that respect most policies provide for coverage up to 10 or 15 billion for material damage and 100 or 200 billion for bodily harm.

The mentioned limitations are rather low, taking into account that the average accident often causes a damage of 10 to 15 billion Belgian francs. Spokesmen informed us that if accidents involving attorneys' liability are reported to the insurer, it concerns apparently only serious cases. The amounts involved are therefore rather high. For these reasons the Bar decided to offer an excess insurance which covers in cases where the actual amount of the damage exceeds the insured amount. ${ }^{16}$

It is important to stress that, as was the case with architects, premiums are not calculated on an individual basis. There is no individualization, neither ex ante (through preliminary control), nor ex post (e.g. through experience rating). All collective policies stipulate a single premium, which is equal for all attorneys of the Bar in question. One should not forget that there is no direct contact between the insured attorney and the insurance company, since the debtor of the premium is the Bar. The Bar passes on the premium to the individual attorney, by calculating it into his membership fee to the Bar. Premiums differ only slightly from Bar to Bar. According to spokesmen this is due to the past loss experience of the Bar in question. Striking is that if several attorneys in one district had many accidents, their individual premium will remain unchanged. Instead, the premium charged to the Bar can raise which will cause an increase in the membership fee to the Bar. ${ }^{17}$

Young attorneys may enjoy a privileged position with respect to the payment of the premium. For instance, in Antwerp, only from the fourth year on, the membership fee is high enough to cover the insurance premium. ${ }^{18}$ Such cross subsidization in favour of younger attorneys can also be found in the Bars of other districts. There is also a cross subsidization

${ }^{14}$ For instacce in the districts of Dendermonde, Dinant, Namur and Veurne.

15 For instance in the districts of Antwerp, Leuven, Mechelen and Oudenaarde.

${ }^{16}$ For instance the Antwerp Bar, where the limitation is set at 15 billion Belgian francs agreed to a collective excess insurance policy to which attorneys can agree on a voluntary basis. In the mailing to all attorneys it was stated not to be an exception that actual liability acceeds the 15 billion coverage. An additional guaranty of 5,10 or 15 billion Belgian francs can be purchased. The premium depends on whether the attorney works alone or has associates. For the alone working attorney the premium is $1.250,2.400$ or 3.500 Belgian francs; for the other : $2.500,4.800$ or 7.000 Belgian francs for 5,10 or 15 billion of additional coverage. Until now 120 of the 1.000 attorneys in Antwerp took this supplementary liability insurance coverage.

${ }^{17}$ For instance the general premium in Antwerp is 6.000 Belgian francs and 5.800 Belgian francs in Hasselt. Remarkable is the situation in Mechelen, where the premium was raised in 1987 from 4.000 to 8.000 Belgian francs.

${ }^{18}$ For the first year membership to the bar the fee is 4.000 ; for the second year 5.000 and for the third year 6.000 Belgian francs. Only from the 4 th year of membership, the fee is 9.000 Belgian francs, which is sufficient to cover the insurance premium of 6.000 Belgian francs. 
from larger to smaller Bars. In small districts with few attorneys the Bar could never bring up an actuarily fair premium. In practice they pay lower premiums, which is compensated by charging relatively more to Bars in lager districts with thousands of attorneys. ${ }^{19}$

There are other typical features of the insurance contract which are worth mentioning, since they influence the amount of the premium. First, some policies expressly state that the insurance company withdraws the right to cancel the insurance policy during the insured period. Other provisions relate to the professional secrecy and the discretion of the attorneys. Most attorneys consider it confidential information that they behaved negligently or they try to avoid bad publicity. For this reason most policies state that after a claim has been reported, the insurer will negotiate with the injured parties. Some provisions stress that disputes will be handled with utmost discretion and that the insurer will try to achieve settlements with the claimant. ${ }^{20}$ In practice, as soon as a claim is reported, the insurer appoints another attorney of the Bar to which the insured attorney belongs. This attorney will try to achieve a settlement. If he advises in favour of a settlement, in most cases the insurer will follow his advice. Hence, a clear proof of the liability of the insured, e.g. in a judgement, is not required. Needless to say that most attorneys would, of course, wish to avoid such a clear judgement. This practice implies that also cases are settled which might have been won in court. The overall effect might be an increase in premiums. However, the Bar is willing to pay this price in order to avoid bad publicity in connection with liability cases.

There are other provisions in the policy which assure the confidential treatment of a liability claim. For instance, disputes with respect to the application of the policy will always be submitted to arbitration. In addition, some policies expressly exclude the right of the insurer to sue third liable parties in a redress action. ${ }^{21}$

The different features of the insurance policy for attorneys are of such a nature that one would expect high premiums. Spokesmen informed us that nevertheless the premiums charged in the collective policy are inferior to those that would be charged in an individual insurance policy. This might be attributed to the bargaining power of the Bar and to the savings on administrative costs by chosing the collective policy.

\section{- Moral hazard and adverse selection}

The control of moral hazard in attorneys' insurance policies is affected by professional ethics, especially the duty to confidentiality. Again the problem with the collective insurance policy is the absence of individualization of premium, neither ex ante, nor ex post. The individual premium of an attorney will not increase, even after a number of serious accidents happened. Moreover, it should not be forgotten that the Bar is the debtor of the premium, which implies that a premium increase will not be applied on the individual attorney. A further characteristic of the insurance policy is the absence of any contact between the insured attorney and the insurance company. Hence, there is no direct monitoring of the

${ }^{19}$ For instance in the district of Veurne the 45 attorneys could never bring up a fair premiun for an insurance coverage of 5 billion Belgian francs. This is compensated by charging relatively more to the bars of e.g. Antwerp and Brussels.

${ }^{20}$ Article 12 of the policy of A.G.F. (which insures e.g. the Bar of Ghent) and of the policy of Royale Belge (which insures e.g. the Bars of Brussels, Turnhout and Hasselt).

21 For instance article 6 of the insurance policy of A.B.B. 
attorney by the insurance company. It is also striking that many Bars do not provide an individual copy of the insurance policy to the attorneys. Even if the insurance policy would contain provisions such as an exclusion of coverage, the individual attorney would have no knowledge of such provisions. ${ }^{22}$ In fact the monitoring of the carefulness of the attorney in treating his case is only performed by the Bar itself. In this respect most Bars organize courses for young attorneys in which all the dangers and risks of liability cases are explained. A further example of the fact that monitoring is totally left to the Bar itself is that every accident which is reported to the insurer, should be reported to the President of the Bar Council. The latter can then decide to take disciplinary sanctions based on the rules of legal ethics against the negligent attorney.

The explanation given is that a direct control by the insurer of the behaviour of the attorney is considered contrary to the freedom and dignity of attorneys. Even if some attorneys pose bad risks, the sanction will in principle be disciplinary. Instead of raising the premium, the attorney can receive a warning or, in serious cases, can even be disbarred. According to spokesmen the raising of premiums is not an adequate means to control moral hazard for attorneys.

Apart from monitoring and raising the premium in accordance with the behaviour of the insured, moral hazard can be controled by exposing the insured partially to risk. This device has been chosen to control moral hazard in attorney's insurance policies. There is an upper limit on coverage. However, it is not the immediate goal of this limit to control moral hazard. Nevertheless, it can have such effect. Suppose that an average accident causes damage of 10-15 billion Belgian francs and that the insurance coverage is substantially lower, insured attorneys could be induced to take care, being partially exposed to risk. The insurance policies do, however, not prohibit the insured to take an additional coverage. This proves that the goal of this limitation is not the control of moral hazard, but the limitation of risk exposure of the insurance company.

The actual device chosen to control moral hazard is the deductible. The deductibles become increasingly important. Originally one generalized deductible of $25 \%$ applied, with a minimum of 10.000 Belgian francs and a maximum of 50.000 Belgian francs. No individualization of the deductible was applicable. Hence, even if one attorney had many accidents, the deductible would not increase, nor would his premium, as was mentioned above. This practice created enormous moral hazard problems. Premiums raised on a general level from 1.500 per attorney in 1978 to 4.000 Belgian francs in 1980 , to 6.000 Belgian francs in 1982. ${ }^{23}$ Still this general premium increase did not cure moral hazard since there was no individual penalization of negligent attorneys. Spokesmen informed us that in the beginning of the 1980's the situation in Antwerp was that bad, that some attorneys even had several accidents in a single month. As a result of this development, attorneys' liability insurance became bad risk and several insurers withdrew from the market. Ten years ago still 20 insurers insured the mentioned risk, whereas now only 5 insurers do.

\footnotetext{
${ }^{22}$ We discovered this, asking several attorneys for their insurance policy. Only in Ghent, Antwerp and some other districts, all attorneys had a copy of the policy. In other districts, e.g. Turnhout only some attorneys have a copy of the policy, which we were not allowed to quote, since it was considered "confidential".
}

${ }^{23}$ This was the situation in Antwerp, where the premium is still 6.000 Belgian francs. 
After it became apparent that most accidents always happened with the same attorneys, in 1983 the Antwerp Bar decided to intoduce an individualized deductible. From November 1983 the following deductible is applicable:

1. Accident : $25 \%$, minimum 30.000 .-; maximum 100.000 Belgian francs

2. Accident : $50 \%$, minimum 60.000.-; maximum 200.000 Belgian francs

3. Accident : $50 \%$, minimum 90.000.-; maximum 400.000 Belgian francs

4. Accident : $100 \%=$ no coverage at all.

This system is valid for a period of 5 years. The obvious function of this deductible is to control moral hazard. Most insurance policies do indeed provide that the deductible may not be insured with another insurance company. This system of an individualized progressive deductible apparently had a positive influence on the accident rate. The premium now has stabilized at 6.000 Belgian francs. From January 1987 the exclusion in case of a fourth accident within 5 years has been canceled.

With respect to the adverse selection problem we can be brief. Spokesmen claim that the collective policies eliminate this problem. All attorneys, who are member of the Bar, have to take the insurance policy, whether they pose good risks or bad.

\subsection{Insurance of the medical profession}

- The insurance policy

In contrast with the situation of attorneys, there are no collective insurance policies which insure a group of doctors as a whole. There is no intervention of the professional organization of doctors to organize the availability of liability insurance. Recently a group of doctors founded an association called Isotoop, which is supposed to provide insurance for doctors on a mutual basis in the near future. The aim of the association will not only be the provision of insurance, but also the assistance of doctors in providing service and information. This association is not operational yet. In addition it should be mentioned that collective policies do exist in some sectors, e.g. for doctors working in a hospital. An example which will be further discussed is the collective policy covering the professional liability of the doctors working in the university hospital of Antwerp. It is interesting to add that the risks are spread among several large Belgian insurance companies through co-insurance. ${ }^{24}$

The content of the insurance policies covering the individual professional liability of doctors is very similar. Most policies cover both the contractual and the third party liability. Nevertheless Fontaine remarks that some policies only cover the extracontractual liability (Fontaine, 26). This insurance schem is less useful in the context of professional liability of doctors, since the victim of a professional accident is most likely to stand in a contractual relationship with the doctor (see 1.2.). The policy offers coverage not only for the personal faults of the doctor, but also for faults of persons for whom the doctor is responsible, e.g. assistants. In the collective policy of the Antwerp university hospital coverage is provided both for the liability of the hospital as such and for the liability of all the persons working in the hospital, e.g. doctors, guest professors and lecturers. It is also interesting that the policy covering the hospital also insures liability caused through faults with human blood.

${ }^{24}$ A.G.-Securitas is leading insurance company, but all of the underwriting companies (Securitas, Eagle Star, Royale Belge, A.B.B.) are having a $25 \%$ participation. 
As was the case for attorneys, also doctors insist upon a confidential treatment of a liability claim by the insurance company. Out of court settlements are often preferred to avoid too much rumour about a case. Some policies give doctors the possibility to negotiate themselves a settlement with the victim. In case the insurance company contacts the victim itself the policy always stipulates that this should be done with utmost discretion and that the insurer should in that case try to reach a settlement. Disputes between the insurance company and the insured doctor are often left to arbitration.

The premium calculation basically depends on two variables: the desired amount of insurance coverage and the type of risks involved. Contrary to the situation with attorneys, doctors are divided in several categories, depending on the work which they are performing. These distinctions make it possible to distinguish whether they pose higher or lower risks. With respect to the amount of coverage, most policies offer a choice between a coverage up to 10,25 or 100 billion Belgian francs for bodily harm and 1,2 or 5 billion Belgian francs for material damage. These amounts are higher in the policy covering the Antwerp university hospital : 600 billion per accident with a maximum of 30 billion per victim for bodily harm and 90 billion for material damage.

Doctors are divided into 5 categories, depending upon the work they perform. Category 1 embraces the doctors posing the lowest risk: general practitioners, labo analysts, gerontologists, psychoanalysts, police physicians. To the highest category belong the neurosurgeons and in general all surgeons. According to the preceding categorization the premium will differ depending upon the type of activity exercised and the amount of coverage chosen. For instance, if a doctor would like to insure his liability with "The Medical" at the highest limit of coverage available (100 billion for bodily harm, 5 billion for material damage) a general practitioner would only pay 2.503 Belgian francs premium per year. For a doctor with a certain degree of specialization the amount would be 3.773 Belgian francs, whereas surgeons would, for the same level of coverage, pay a premium of 18.000 Belgian francs per year. ${ }^{25}$ Only the premium calculation in the collective policy covering the Antwerp university hospital is different. There the premium is dependent on the gross wages paid by the hospital to all the members of their personnel.

\section{- Moral hazard}

The moral hazard problem appears under the same features in the liability insurance of doctors. There is, as has been described, in this case a certain individualization and separation in different risk groups. Based on experience, higher premiums are charged for surgeons than for general practitioners. However, in the risk group itself, no further individualization is done to whether someone poses a high or a low risk in his own category, e.g. as surgeon. Ex ante a simple form is sent to all potential insured in which is only asked to which category the doctor belongs; which amount of coverage he is willing and whether his policy has been canceled by a previous insurance company and if so, for what reason. The premium is set based on this proposal and is theoretically equal for all insured in the same category. Apparently there is no individual monitoring of the insured doctors ex ante. Also ex post a serious monitoring by the insurance company is lacking. Even if many accidents happen, no premium increase will be applied. Moral hazard becomes incurable if one

\footnotetext{
${ }^{25}$ See also Anrys, 313.
} 
realizes further that in none of the insurance policies covering doctors' liability deductibles are applied. Spokesmen told us that only in case of too many accidents the insurance company threatens to introduce a deductible or to cancel the policy at all. As has been described in the section devoted to architects' liability insurance, moral hazard is only controled on an "all or nothing" basis.

\section{Section IV:}

\section{Analysis and perspectives of compulsory liability insurance for professionals}

In section II several arguments have been advanced to explain the introduction of compulsory liability insurance. After the description of the existing compulsory liability insurance schemes for professionals in Belgium, we can now reconsider those arguments, taking into account this insurance practice.

Referring to the expected utility maximization hypothesis, it seems fairly obvious that compulsory liability insurance will only increase social welfare if actual premiums do not highly exceed the actuarily fair level of premiums and if they correspond with the individual demand for insurance of the insured involved. The description of the insurance practice in Belgium has demonstrated that for several reasons premiums are rather high. First, it should be stressed that there is no detailed individualization of premiums. Although there is some classification of risks in the case of doctors and architects, there is no such classification at all in the case of attorneys. This has several consequences. For those professionals posing good risks, premiums will be relatively high. If insurance is made compulsory under these conditions, it will not lead to an increase in social welfare. Second, there is a redistribution from the good risks to the bad ones. Third, the lack of individualization of premiums will create both moral hazard and adverse selection problems.

This lack of individualization of premium is sustained by the ethical rules of the professional organizations. A detailed individualization of premiums which would show which professionals are the good and which are the bad risks, would be contrary to the independence and dignity of professionals. Classification of risks is of course desirable from an insurance point of view. However, a detailed classification might generate more costs than benefits. A classification which would take into account differences between professionals, such as age and the grade obtained at university, might be more costly than the advantage in individualization of premiums. However, often classification can be performed at low costs. For instance, with respect to attorneys, one could easily distinguish between the types of cases an attorney is treating: divorce cases, traffic accidents or corporate law. Even this classification is not applied. The rules of legal ethics prohibit such classification; attorneys are even not allowed to indicate their specialization.

To remedy these inefficiencies of compulsory liability insurance for professionals, one could suggest to remove the institution of compulsory liability insurance and its control from the professional organizations. However, even insurers seem to be very reluctant to make detailed categorizations of professionals, taking into account their qualifications. This can be illustrated by the case of doctors. Although liability insurance in that case is organized without an intervention of the professional organization, no detailed individualization is applied, even though this could be efficient. Apparently insurers consider themselves unable to monitor members of "a respectable profession" (Dingwall and Fenn). Therefore 
removing the liability insurance from the professional organization is not a complete solution as long as the insurers consider themselves unable to judge the quality of the performed services by the professional.

Premiums exceed the actuarily fair level not only because a lack of individualization, but also due to the desire for secrecy inherent in professional ethics. Both in case of doctors' and attorneys' liability insurance, the insured professional has the right to negotiate with the injured person on a liability claim and such settlement will in principal be honoured by the insurance company. Hence, the insurance company will often pay, even if liability has not been established in a court decision. This will of course lead to an increase of premiums.

Our research has shown that compulsory liability insurance for professionals in the mentioned cases has not explicitly been based on the insolvency argument. Of course, in some cases, especiallly with young professionals, a serious insolvency risk might exist. However, in this respect we refer to the discussion in chapter II, often other mechanisms are at hand to cure the insolvency problem at lower costs.

Information problems constituted the main reason for the introduction of compulsory liability insurance for architects and attorneys. The professional organizations argued that some professionals did not realize to what risks they were exposed; compulsory liability insurance should protect them against ruining their career. The validity of this argument has already been discussed above. In conceals paternalistic motives. With respect to the compulsory liability insurance for attorneys it should be stressed that the main motive was the protection of the dignity of the Bar as a whole.

This paper has indicated that the most serious problem in the area of compulsory liability insurance for professionals in Belgium is an almost incurable moral hazard problem. Due to already mentioned rules of professional ethics, almost no monitoring by the insurance company is possible. The ex ante monitoring is very limited. Even ex post there is in fact no penalization of careless behaviour of the insured professional through a premium increase. In none of the three examined cases, premiums are raised after an accident has happened. Hence, the only available way to cure moral hazard is exposing the insured professional partially to risk. First it should be mentioned that the upper limit on coverage does not function as a remedy to moral hazard. The amount of the limitation can often be chosen by the insured professional and in addition there is no objection against an excess insurance. Hence, these upper limits on coverage are no adequate devices to control moral hazard and seem only relevant to the risk calculation by the insurer. Most striking is the situation of doctors, where there is even no deductible applicable. In the case of architects and attorneys a deductible is applied. Interesting is that the deductible can apparently be effective to control moral hazard. The case of attorneys showed that the progressive deductible decreased the accident rate substantially. Striking is that in the case of architects and doctors moral hazard is in principle not controled during the performance of the contract; if the injured professional has, in the eyes of the insurer, caused too many accidents, his policy will simply be canceled.

In chapter II it was mentioned that in the evaluation of the efficiency of compulsory liability insurance also the market structure of the insurance markets involved should be considered. If a high degree of concentration on the market would exist, premiums would not only be too high, but the incentives to control moral hazard could be reduced as well. This can now briefly be examined. 
Concerning the liability insurance for architects, ARCO claims that even though the market is small, competition does exist. ARCO claims that there are no agreements on price with the other insurance companies. In conversations with architects, we were told that the differences in premiums are small. In their view only secondary policy conditions, e.g. coverage on a claims made basis or not, constitute the main difference between the insurance companies involved. It is clear that the information provided by insurers and insured does not provide a definitive answer to the question whether the market is competitive or not. There is whatsoever reason for scepticism as to the competitiveness of the market, because the insurance market involved is oligopolistic in its structure. This leaves little room for competition.

Concerning the liability insurance for attorneys, there is, according to spokesmen, no real price competition between the insurers. This can also be understood. In most cases several or all of the five possible insurers covering the mentioned risk co-insure the professional liability of attorneys. This finding gives strong support for the brokers' view that premium competition is restricted. The concentration on the insurance market will reinforce the above mentioned negative effects on efficiency of compulsory liability insurance.

We will now come to the distributive effects. The effect of the insufficient subcategorization will increase the average premium at a too high level for the good risks. Hence, they crosssubsidize the bad risks. This adverse effect on redistribution is not unique to professional liability; it can also be found in strict liability schemes (Priest). In addition, as far as attorneys are concerned, there are two other redistributive effects. The larger Bars crosssubsidize in fact the Bars in smaller districts. Older attorneys also subsidize younger attorneys since the latter do not have to pay the full premium.

It seems relevant to discuss three other aspects of compulsory insurance for professional liability. When society decides to make liability insurance compulsory for a certain activity, the question arises whether the insurance market is willing to provide the required insurance. This might be a problem in the field of professional liability insurance, given its technicity. Practical evidence seems to support this uncertainty. In all the fields of liability insurance discussed in this paper, either the risk was insured by an insurance company specialized in professional liability (ARCO, The Medical) or the number of traditional insurance companies which insured the risk was very restricted (in the case of the attorneys). This can be attributed to the fact that the demand side of insurance is often restricted to a limited number of professionals. Hence, the risk of high concentration of the insurance market can be better understood. Once again compulsory liability insurance seems to create more problems than it solves.

Also the enforcement problem should be addressed. If compulsory liability insurance for professionals would be desirable on efficiency grounds, it should be asked whether this duty to insure should be enforced by the state or by a professional organization. Our research pointed at the weaknesses of the latter solution. Inefficiencies can be created due to the attitude of professional ethics. The disadvantage is also that society becomes totally dependent on the professional organization. The case of architects showed that reluctance within the organization to enforce the duty to insure will result in an overal non-enforcement. It seems therefore more appropriate to enforce the duty to insure through staturory sanctions. 
A last question is whether the technique of collective insurance policies has advantages in comparison with insurance policies on an individual level. One could expect lower premiums with collective policies, since transaction costs could be expected to be lower. However, the disadvantage remains that collective policies inhibit an efficient individualization of premiums. With respect to the Belgian case our empirical evidence is modest. Spokesmen informed us that the premiums in the case of liability insurance for attorneys are basically lower in the collective policy. However, it would be premature to draw conclusions on this finding. Definitive answers on this problem can only be given after an examination of premiums in an individual insurance policy in a perfectly competitive market.

\section{Conclusion}

On the basis of criteria in favour of compulsory liability insurance this paper has examined the existing insurance schemes for certain professional services in Belgium. Although one has to be careful with generalizing conclusions, some striking similarities in the three cases were found. For a number of reasons premiums exceed actuarily fair levels. First, there is the lack of individualization of premiums. Second, certain rules of professional ethics, especially those concerning the desire for secrecy, increase premiums. Finally, also concentration on the insurance market will lead to a premium increase.

Another common feature of liability insurance in the cases under discussions is the absence of an effective control of the moral hazard problem. Professional ethics inhibit a direct control by the insurance company of the insured professional. The upper limit on coverage does not function as a remedy to moral hazard. Deductibles are rare.

Given the negative effects on premiums and on incentives to take care, liability insurance in the cases under discussion creates several inefficiences. The effect of making such system compulsory would therefore overall be negative. On the policy level one should therefore be cautious to advocate compulsory liability insurance. If problems as they exist in Belgium are incurable, a suboptimal result will follow.

Finally, it also seems doubtful whether removing the compulsory insurance from the professional organization will in itself be able to solve all mentioned problems. Especially the respect for the profession by the insurers seems an important ground of the described inefficiencies. Only as far as the enforcement of a duty to insure is concerned one can be quite certain about the beneficial effects of statutory sanctions instead of sanctions based on professional ethics.

\section{REFERENCES}

ADAMS, M., (1985), Oekonomische Analyse der Gefährdungs- und Verschuldenshaftung, Berlin, Decker's Verlag.

ACKERLOF, G., (1970), "The market for 'lemons': quality, uncertainty and the market mechanisms", Quarterly journal of economics, 84, 488-500.

ANRYS, H., (1974), La responsabilité civile médicale, Brussel, Larcier.

ARROW, K., (1965) Aspects of the theory of Risk-Bearing, Helsinki, Yrjö Johnssonin Säätiö.

BEECK, L., (1987), De aansprakelijkheid in de bouw gezien vanuit een andere hoek, Gent, Vyncke. 
BAERT, G., (1985-86), "Het nieuwe reglement op de beroepsplichten van de architect", $R$. W., 14571468.

BORCH, K., (1963), "Recent Developments in Economic theory and their Application to insurance", The Astin Bulletin, 2, 322-341.

BOULANGER, J., (1986), "De 'verplichte' verzekering van de architect", Verzekeringswereld, 21 -23.

de GRYSE, L., (1979), "De beroepsaansprakelijkheid van advocaten", in Onrechtmatige daad, actuele tendensen, Antwerp, Kluwer, 107-115.

DEPUYDT, P., (1983), De aansprakelijkheid van advocaten en gerechtsdeurwaarders, Antwerp, Kluwer.

DINGWALL, R. and FENN, P., (1987), "A respectable profession. Sociological and economic perspectives on the regulation of professional services", International Review of Law and Economics, 51.

DUTRY, G., (1969), L'assurance de la responsabilité civile, principalement de l'architecte et subsidiairement de l'entrepreneur, Brussel.

FAGNART, J. L., (1985), "La responsabilité civile (1976-1984)", J. T., 453-470.

FINSINGER, J., (1983), Versicherungsmärkte, Frankfurt-New York.

FONTAINE, M., (1983), L'assurance de la responsabilité civile professionelle des professions juridiques et médicales, Louvain, Centre de droit des obligations.

JOHNSON, W., (1977), "Choice of compulsory insurance under adverse selection", Public Choice, 31, 23-35.

KAHNEMANN, D. and TVERSKY, A., (1979), "Prospect theory: An analysis of decision under risk", Econometrica, 47, 263-291.

KRUITHOF, R., (1982-83), "Tendensen inzake medische aansprakelijkheid”, Vlaams Tijdschrift voor Gezondheidsrecht, 177-197.

LANDES, W. and POSNER, P., (1984), "Tort law as a regulatory regime for catastrophic personal injuries", Journal of legal studies, 13, 417-434.

PAULY, M., (1974), "Overinsurance and public provision of insurance: the roles of moral hazard and adverse selection", Quarterly journal of economics, 88, 44-62.

PRATT, J., (1964), "Risk Aversion in the Small and in the Large", Econometrica, 32, 122-136.

PRIEST, G., (1987), "Modern tort law and the current insurance crises". Yale law journal, 96, 1521 1590.

RAVIV, A., (1979), "The Design of an Optimal Insurance Policy", American Economic Review, 69, 84-96.

RIGAUX, P., (1975), L'architecte, le droit de la profession, Brussel, Larcier.

ROTHSCHILD, M. and STIGLITZ, J., (1976), "Equilibrium in competitive insurance markets: an essay on the economics of imperfect information", Quarterly journal of economics, 90, 629-649.

SHAVELL, S., (1979), "On moral hazard and insurance", Quarterly journal of economics, 93, 541 562.

SHAVELL, S., (1986), "The judgment proof problem", International review of law and economics, 6 , $59-75$.

SHAVELL, S., (1987), Economic analysis of accident law, Cambridge, Harvard University Press.

VANDENBERGHE, H., (1979), "Aansprakelijkheid van ziekenhuizen en geneesheren", in: Onrechtmatige daad, actuele tendensen, Antwerp.

Van EMPEL, M. en RITSEMA, H., (1987), Aansprakelijkheid voor producten, Deventer, Kluwer. 